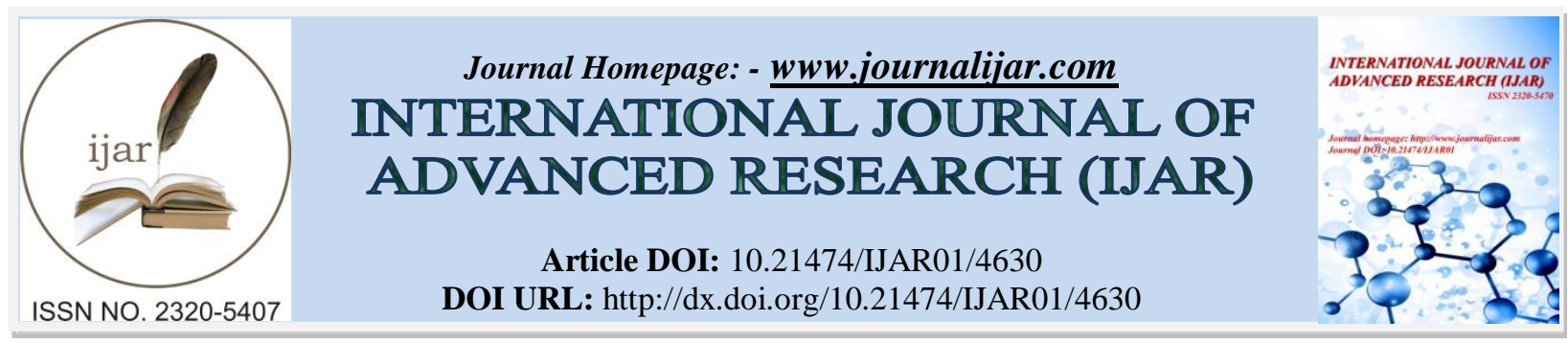

SHORT COMMUNICATION

\title{
BACTERIOLOGICAL ASSESSMENT OF RASGULLA SYRUP SOLD AT DIFFERENT SHOPS OF SILCHAR, ASSAM, INDIA.
}

Satabdi Bhattacharjee ${ }^{1}$, Nandan Bhattacharjee ${ }^{2}$, Bibhas Deb ${ }^{1,2}$ and ${ }^{*}$ Soumitra Nath ${ }^{2}$.

1. Institutional Biotech Hub, Gurucharan College, Silchar, Assam, India.

2. Department of Biotechnology, Gurucharan College Silchar, Assam, India.

\section{Manuscript Info}

Manuscript History

Received: 27 April 2017

Final Accepted: 29 May 2017

Published: June 2017

Key words:-

Rasgulla, health effects, bacteria, contamination

\begin{abstract}
Sweet prepared from milk is an integral part of the culinary habits of people all over India. However, their rich nutrient content also provides an excellent environment for microbial growth. Ingestion of contaminated sweets are responsible for many foodborne diseases.

In the present study, 28 rasgulla syrup samples were collected from different sweet shops of Silchar, Assam, India and their bacteriological assessment were performed. Total microbial load ranges from $1.52 \times$ $10^{4}$ to $9.38 \times 10^{4} \mathrm{cfu} / \mathrm{ml}$ and the isolates were identified as Escherichia coli, Staphylococcus spp. and Bacillus spp, comprising 68\% of total isolates. Few strains of Klebsiella spp., Pseudomonas spp., Salmonella spp. and Shigella spp. were also observed, which often causes serious health effects. The findings of the present study revealed that the rasgulla syrup sold at different street shops of Silchar city constitute a diverse environmental bacteria. However, maintaining aseptic conditions during procurement, processing and distribution may reduce the bacterial contamination and increase the quality of rasgulla.
\end{abstract}

Copy Right, IJAR, 2017,. All rights reserved.

\section{Introduction:-}

Indigenous dairy product is playing a major role in our society, and among them Rasgulla is regarded as the king of Indian milk sweets (Ahmad and David, 2017). People of all age groups usually use milk and dairy products as a dietary and high-grade food. It contains the major elements like proteins, fat, sugar, minerals, vitamins etc. which are required for growth and maintenance of the body (Jain et al., 2014). However, at suitable conditions, milk products provide an excellent condition for the growth of the microorganism. Unhygienic practices also lead to early spoilage (Oliver et al., 2005), leading to food poisoning and food borne diseases (Ozha, 2016).

Rasgulla is a syrup based sweet dish made from milk product called 'Channa' (Indian cheese) and cooked in syrup made of sugar. Manufacturing of sweets and sweet syrup is based on traditional methods without maintaining the quality of the raw material used. As a result, these products are extremely vulnerable to contamination with pathogenic organisms as well as toxic metabolites of microbes. The presence of Enteropathogenic bacteria causes food poisoning, resulting in severe diarrhoea and vomiting. So, to improve the microbiological quality and protect public health against milk-borne infections, precautions against contamination must be taken at different critical control points (Roy et al., 1998). The knowledge about the microbial contaminants of sweet syrup is of great significance for the development of hygienic and healthy practices. Thus, the present study evaluated the bacteriological quality of sweet syrups sold at various sweet shops of Silchar, India. 


\section{Methodology:-}

Rasgulla syrup samples were randomly collected from 28 different sweet shops of Silchar city, Assam, India. Handling by the workers and hygienic conditions of the shops were also noted. The samples were collected in a sterile plastic sampling bags kept in a cold box and then immediately brought to the laboratory for further studies. Serial dilutions of the syrup were prepared using sterile saline water. Samples were spread on agar plates and were incubated at $37^{\circ} \mathrm{C}$ for 24 hours. The total bacterial count was determined by counting the colonies in microprocessor colony counter. Individual distinct colonies were sub-cultured and were identified on the basis of colony morphology (shape, structure, colour, pattern, size), Gram's staining and biochemical tests (Indole production, Methyl red, Voges-Proskauer, citrate utilization and starch hydrolysis) (Cappuccino et al., 2008; Dubey et al., 2014).

\section{Results and Discussion:-}

The unhygienic condition of food handlers and lack of proper storage plays a vital role in sweet and dairy product contamination. Maximum bacterial load was observed due to improper handling and processing of food items, which directly contributes to microbial contamination (Sharma and Mazumder, 2014). In the present study, bacterial load in the syrup samples ranges from $1.52 \times 10^{4} \mathrm{cfu} / \mathrm{ml}$ to $9.38 \times 10^{4} \mathrm{cfu} / \mathrm{ml}$. Among all the isolated bacteria, Escherichia coli, Staphylococcus spp. and Bacillus spp. comprises $68 \%$ of the total microbial load. Chatli et al., (2014) isolated bacteria from rasgulla and panner, having viable microbial count $2.8 \times 10^{4} \mathrm{cfu} / \mathrm{ml}$ and $6.7 \times 10^{4}$ cfu/ml respectively. Vaishnavi et al., (2001) reported a viable microbial load of $3 \times 10^{2}$ to $9.7 \times 10^{10} \mathrm{cfu} / \mathrm{ml}$ in sweet and milk products. The unhygienic environment in preparation, processing, packaging and storage are often so poor that the foodstuffs on reaching the customers have an enormous microbial load, which may comprise of different strains of pathogens that cause the serious health hazards. Few strains of Klebsiella spp. (7\%), Pseudomonas spp. (4.6\%), Salmonella spp. (13\%) and Shigella spp. (7.4\%) were recovered from the syrup samples, inferring the cause of alimentary intoxications by consumers. Staphylococcus spp. contamination was coming presumably from the hands of the rasgulla syrup handlers. Escherichia coli frequently occur in indigenous sweet milk products such as Rasgulla and Rasmalai (Kumar et al., 2011). The majority of $E$. coli rods do not constitute a serious health hazard, but some serotypes can cause food poisoning. Similar result were reported by other researchers who found E.coli in milk samples (Zeihnom et al. 2014; Ozha, 2016), Salmonella spp. in rasgulla and paneer (Akhtar et al., 2014; Vaishnavi et al., 2001), Klebsiella spp. in burfi, rasgulla, paneer and ice-cream (Bhatnagar et al., 2007; Tambekar, 2010). The qualitative analysis of the syrup samples revealed the presence of wide range of pathogenic bacteria, indicating serious health hazard and foodborne illness.

\section{Conclusion:-}

This study concludes that unhygienic processing, poor quality of raw materials and unsafe water for washing the utensils could be the main factors responsible for the microbial deterioration of the rasgulla syrup products. Therefore, efforts should be made on educating the food handlers, improving the environmental conditions under which the trade is carried out and maintaining hygienic condition while food preparation and package, may reduce the risks of contamination.

\section{Acknowledgements:-}

The authors sincerely acknowledge Department of Biotechnology, Gurucharan College, Silchar to carry out the work. The authors also acknowledge Institutional Biotech Hub (Funded by DBT, New Delhi) for providing laboratory facility to complete the work.

\section{References:-}

1. Ahmad A and David J (2017). Effect of different levels of low-calorie sweetener aspartame on sensory attributes of diabetic Rasgulla, The Pharma Innovation Journal, 6(5): 82-84.

2. Akhtar S, Sarker MR and Hossain A (2014). Microbiological food safety: a dilemma of developing societies. Critical reviews in microbiology, 40(4): 348-359.

3. Bhatnagar P, Khan AA, Jain, M and Jain SK (2007). Bacteriological Study of Khoa Sold in Gwalior and Morena City (Madhya Pradesh) in Relation to Public Health. Asian Journal of Experimental Sciences, 21(1): 55-62.

4. Cappuccino JG and Sherman N (2008). Microbiology: a laboratory manual (Vol. 9). Boston, MA: Pearson/Benjamin Cummings. 
5. Chatli AS, Tangri R, Chawla H and Komal R (2014). Microbial Quality Evaluation of Milk Products. International Journal of Development Research, 4(12): 2623-2628.

6. Dubey RC and Maheshwari DK (2014). Practical microbiology. S. Chand Pvt. Limited.

7. Jain R, Handa A, Tiwari D, Jain P and Gupta A (2014). Nutrition in diabetes. Journal, Indian Academy of Clinical Medicine, 15(2): 125-131.

8. Kumar H, Sharma D, Palaha R, Sharma P and Sonkusale S (2011). Isolation of Escherichia coli from indigenous sweet milk products in relation to public health sold at sweet-meat shops of Jalandhar city, India. Internet Journal of Food Safety, 13: 332-335.

9. Oliver SP, Jayarao BM and Almeida RA (2005). Foodborne pathogens in milk and the dairy farm environment: food safety and public health implications. Foodbourne Pathogens \& Disease, 2(2): 115-129.

10. Ozha A (2016). A Microbiological Investigation of E. coli and Salmonella on Milk and Non-milk Sweets in Indore Region. International Journal of Engineering Science, 6(9): 3038-3042.

11. Ozha A (2016). A Microbiological Investigation of E. coli and Salmonella on Milk and Non-milk Sweets in Indore Region. International Journal of Engineering Science, 3038.

12. Roy R, Chakrabarti J and Gandhi RS (1998) Microbiological quality-assurance of milk sweets (Sandesh and Kalakand) by HACCP. Indian Dairyman. 50(4): 67-71.

13. Sharma I and Mazumdar JA (2014). Assessment of bacteriological quality of ready to eat food vended in streets of Silchar city, Assam, India. Indian journal of medical microbiology, 32(2), 169.

14. Tambekar DH and Bhutda SA (2010). Prevalence of Bacterial Pathogens in Pedha(A Milk Product) Sold in Amravati(India). International Journal of Dairy Science, 5(3), 173-176.

15. Vaishnavi C, Singh S, Grover R and Singh K (2001). Bacteriological study of Indian cheese (paneer) sold in Chandigarh. Indian journal of medical microbiology, 19(4), 224.

16. Zeinhom MM and Abdel-Latef GK (2014). Public health risk of some milk borne pathogens. Beni-Suef University Journal of Basic and Applied Sciences, 3(3), 209-215. 